\title{
Gambaran Resiliensi Remaja Penderita Luka Bakar di Panti Asuhan
}

\author{
Nesya Ayu Pertiwi, Vinaya, Yusuf Hadi Yudha \\ Fakultas Psikologi, Universitas Pancasila \\ J1. Raya Lenteng Agung, Srengseng Sawah Jagakarsa, \\ Jakarta Selatan 12640, Indonesia \\ vi315naya@gmail.com \&yudha.psycho@gmail.com
}

\begin{abstract}
Fire incidents which have caused wounds and burns may negatively affected for psychological aspect of the victims. A part of physical damages they experienced, the accident may cause lost of family members whom they love, that lead them to live orphanage as they do not have family as well as home and have to face tough conditions and pressures in their lives. Patients with burns who are able to develop resilience capabality can adjust them-selves to adapt well, and even managed to become a better individual. The aim of this research is to know the resilience capability and the factors affecting resilience in adolescence with burns that live in orphanage. This research used qualitative approach with interview and observation in one respondent.This research shows description about that resilience capability in teenager that having burns who live in the orphanage and its risk and protective factors .
\end{abstract}

Keyword: resilience; adolescence; patient with burn; orphanage

\begin{abstract}
Abstrak-Peristiwa kebakaran yang menyebabkan luka bakar kerap menimbulkan pengaruh negatif secara psikologis terhadap diri penderitanya. Selain kerusakan fisik yang dialaminya, peristiwa tersebut dapat pula mengakibatkan hilangnya anggota keluarga yang dicintai, yang mengharuskan penderitanya tinggal di Panti Asuhan, karena sudah tidak memiliki keluarga dan tempat tinggal, lagi dan juga harus berhadapan dengan kondisi-kondisi sulit dan menekan dalam kehidupannya. Penderita luka bakar yang mampu mengembangkan kemampuan resiliensinya dengan baik dapat menyesuaikan diri, bangkit, bahkan berhasil menjadi individu yang lebih baik. Tujuan dilakukannya penelitian ini adalah untuk mengetahui gambaran kemampuan resiliensi dan faktor-faktor yang mempengaruhi resiliensi pada remaja penderita luka bakar yang tinggal di Panti Asuhan. Pendekatan yang digunakan dalam penelitian ini adalah pendekatan kualitatif dengan teknik wawancara dan observasi yang dilakukan pada satu subjek yang rentang usianya termasuk dalam usia remaja yang memiliki luka bakar dan harus tinggal di panti asuhan. Hasil penelitian ini menjabarkan deskripsi kemampuan resiliensi pada remaja penderita luka bakar yang tinggal di panti asuhan, dengan berbagai faktor risiko dan protektifnya.
\end{abstract}

Kata kunci: resiliensi; remaja; penderita luka bakar; panti asuhan. 


\section{PENDAHULUAN}

Kebakaran, ledakan, kecelakaan yang berhubungan dengan suhu yang tinggi (yang disebabkan oleh zat cair panas, zat kimia, tegangan listrik dan sebagainya), merupakan peristiwa yang cukup sering terjadi di Indonesia. Menurut data dari Dinas Kebakaran dan Penanggulangan Bencana Provinsi DKI Jakarta tercatat 46 peristiwa kebakaran di DKI Jakarta sejak 1 Januari 2009 sampai 19 Juni 2010 (Afz, 2010). Sebuah angka yang cukup besar dalam jangka waktu yang singkat. Peristiwa tersebut hampir selalu membawa korban baik korban jiwa ataupun korban luka bakar.

Berdasarkan data kebakaran (Poerwantoro, 2008) di Provinsi DKI Jakarta pada 2007-2008 menunjukkan bahwa lebih dari 100 orang menderita luka bakar akibat kebakaran. Data ini pun dianggap belum menggambarkan seluruh penderita luka bakar karena tidak adanya penghitungan statistik terintegrasi dari rumah sakit- rumah sakit, Balai Kesehatan dan Departemen Kesehatan.

Pengertian dari luka bakar sendiri dapat diartikan sebagai kerusakan fisik pada manusia yang disebabkan oleh zat yang bersuhu tinggi atau yang dapat memicu suhu tinggi, baik karena reaksi kimia maupun reaksi fisika (Poerwantoro, 2008). Luka bakar dapat diklasifikasi melalui luas area tubuh yang terkena, derajat kedalaman dan keparahan, serta lokasi-lokasi tubuh yang terkena luka bakar.

Petterson (2000 dalam Fauerbach, Heinberg, Lawrence, Bryant \& Richter, 2002) menyatakan bahwa luka bakar terjadi secara tiba-tiba, dan merupakan kejadian sangat buruk dan mengancam kehidupan seseorang yang menimbulkan penyesuaian jangka pendek (seperti rasa sakit, penurunan kondisi fisik secara umum) dan jangka panjang (seperti kerusakan penampilan). Seseorang yang menyandang luka bakar di tubuhnya harus melalui masa penyesuaian yang tidak mudah dalam merasakan sakit yang luar biasa saat peristiwa baru terjadi, saat masa perawatan luka, dan saat menerima kondisi fisik yang tidak berfungsi seperti sebelumnya hingga kerusakan penampilan. Banyak penderita luka bakar yang memenuhi kriteria Post Traumatic Stress Disorder (PTSD) (Fauerbach, Powers, Cruse, Daniels \& Stevens 2000 dalam Fauerbach dkk. 2002), dan diikuti dengan ketidakpuasan akan body image yang signifikan BID (Body Image Disorder) (Dowrence, 2000 dalam Fauerbach dkk., 2002). Patterson, Thompson dan Kent, Van Loey (2000 dalam Lawrence, Fauerbach \& Rosenberg, 2007) menyatakan bahwa sebagian besar penderita luka bakar mengalami masalah self-esteem dan depresi.

Selain dampak dari kebakaran yaitu luka bakar yang dialami seseorang, keadaan menjadi lebih sulit ketika peristiwa kebakaran juga menyebabkan hilangnya orangtua dan anggota keluarga yang dicintai. Apalagi jika peristiwa tersebut mengakibatkan individu harus hidup di panti asuhan karena tidak ada anggota keluarga yang bisa merawatnya.

Panti asuhan sendiri adalah suatu lembaga usaha kesejahteraan sosial yang mempunyai tanggung jawab untuk memberikan pelayanan kesejahteraan sosial kepada anak terlantar dengan melaksanakan penyantunan dan pengentasan anak terlantar, memberikan pelayanan pengganti fisik, mental dan sosial pada anak asuh, sehingga memperoleh kesempatan yang luas, tepat dan memadai bagi perkembangan kepribadiannya sesuai dengan yang diharapkan sebagai bagian dari generasi penerus cita-cita bangsa dan sebagai insan yang akan turut serta aktif di dalam bidang pembangunan nasional (Departemen Sosial Republik Indonesia (1997:4)

Margareth (1990, dalam Hurlock, 1995) dalam laporan hasil penelitiannya menyimpulkan bahwa perawatan anak di yayasan panti asuhan cenderung kurang baik, karena anak dipandang sebagai makhluk biologis bukan sebagai makhluk psikologis dan makhluk sosial. Padahal selain pemenuhan kebutuhan 
fisiologis, anak membutuhkan kasih sayang bagi perkembangan psikis yang sehat seperti halnya vitamin dan protein bagi perkembangan biologisnya. Hasil dari penelitian Margareth (1990, dalam Hurlock, 1995 ) menunjukkan gambaran kebutuhan psikologis anak panti asuhan; kepribadian inferior, pasif, apatis, menarik diri, mudah putus asa, dan penuh dengan ketakutan dan kecemasan, sehingga anak akan sulit menjalin hubungan sosial dengan orang lain. Selain itu, mereka juga menunjukkan perilaku yang negativis, takut melakukan kontak dengan orang lain, lebih suka sendirian, menunjukkan rasa bermusuhan, dan lebih egosentris. Mengingat usia mereka yang relatif muda sehingga perubahan ke arah positif dari aspek kepribadiannya masih dimungkinkan.

Dari berbagai fenomena kehidupan di dalam panti asuhan tersebut, banyak sekali dampak psikologis yang negatif dari penderita luka bakar yang berada di panti asuhan. Selain membutuhkan penyesuaian dengan kehidupan di panti asuhan, para penderita luka bakar juga harus mempunyai kemampuan yang baik dalam hal penyesuaian terhadap perubahan baik jangka panjang maupun jangka pendek terkait dengan luka bakarnya. Menurut Joseph (dalam Isaacson, 2002) individu yang mampu untuk beradaptasi dengan cepat terhadap situasi yang baru, mampu memanipulasi dan membentuk lingkungan untuk dapat menghadapi tekanan-tekanan yang ada dengan sukses disebut individu yang resilien.

Menurut Gilgun (2002, dalam Bautista, Roldan \& Graces-Bacsal, 2007), resiliensi didefinisikan sebagai kapasitas individu untuk menghadapi berbagai tantangan dalam hidup, untuk pulih kembali dari pengalaman tersebut, dan meneruskan hidup dengan normal. Penelitian yang sudah ada mengenai penderita luka bakar antara lain mengenai self esteem, body image, dan dampak negatif secara psikologis pada penderita luka bakar. Oleh karena itu, dalam penelitian ini akan diteliti mengenai bagaimana gambaran kemampuan resiliensi pada remaja penderita luka bakar yang berada di panti asuhan, karena mengingat remaja yang memiliki luka bakar dan kehilangan orang tua akibat kebakaran tersebut akan terus mengalami penyesuaian jangka panjang dan tekanan-tekanan yang jauh lebih berat dibandingkan dengan remaja yang masih memiliki orang tua dan memiliki bentuk tubuh yang sempurna, dalam arti tidak memiliki kecacatan dalam tubuh.

Menurut Reivich dan Shatte (2002), dinamika kemampuan resiliensi terdiri dari tujuh dimensi yaitu, regulasi emosi, pengendalian impuls, optimis, efikasi diri, analisis kausal, empati, dan reaching out. Gambaran tiap-tiap dimensi resiliensi tersebut bervariasi bagi setiap individu. Penelitian ini bersifat kualitatif yang bertujuan untuk mengetahui gambaran secara mendalam tujuh dimensi kemampuan resiliensi dan faktorfaktor yang mempengaruhi resiliensi pada penderita luka bakar yang berada di panti asuhan. Kemampuan resiliensi yang dimiliki oleh masing-masing individu bervariasi satu sama lain dan unik, dipengaruhi faktor protektif dan faktor risikonya. Werner dan Smith (dalam Benard, 2004) menyatakan bahwa keberhasilan individu dalam menghadapi masalah dalam hidupnya tergantung pada keseimbangan antara faktor risiko dan faktor protektif. Faktor risiko dapat berasal dari kondisi budaya, ekonomi, atau medis yang menempatkan individu dalam risiko kegagalan memulihkan diri dalam menghadapi situasi yang sulit (Christle, Jolivette \& Michael, 2000), sedangkan faktor protektif dapat berupa trait, kondisi, dan situasi yang dapat mengubah prediksi dari hal-hal negatif serta membuat individu mengelakkan stressor dalam hidupnya (Benard, 2004). Dalam menghadapi masalah-masalahnya, remaja penderita luka bakar yang harus tinggal di panti asuhan, bisa saja menjadi individu yang mampu mengatasi masalahnya. Oleh karena itu, untuk menggali dinamika kemampuan resiliensi dari individu sehingga diperoleh gambaran yang mendalam mengenai resiliensi pada remaja penderita luka bakar, maka dibutuhkan pendekatan kualitatif dengan teknik pengambilan data wawancara dan observasi. 
Subjek yang dijadikan partisipan pada penelitian ini adalah penderita luka bakar yang berada di panti asuhan, dan berusia 11-20 tahun yang merupakan usia remaja. Menurut Papalia, Old dan Feldman (2007), usia 11-20 tahun merupakan usia masa remaja. Masa remaja sendiri dipilih karena pada masa ini terjadi perubahan besar secara fisik, intelektual dan emosi pada seseorang yang menyebabkan kesedihan dan kebimbangan (konflik) pada yang bersangkutan, serta menimbulkan konflik dengan lingkungannya (Seifert \& Hoffnung, 1987). Transisi perkembangan inilah yang memberikan tantangan yang lebih berat lagi kepada remaja penderita luka bakar yang tinggal di panti asuhan seiring dengan munculnya tugas-tugas perkembangan yang ada pada masa remaja ini. Peneliti memilih subjek remaja karena masa remaja juga membutuhkan proses penyesuaian tersendiri terhadap masalah luka bakar yang diderita. Tantangan lebih besar lagi jika subjek berada di panti asuhan dengan isu-isu penyesuaian lainnya, seperti isu ketatnya kehidupan di panti asuhan, yang mengharuskan penghuni yang tinggal di panti asuhan tersebut hidup mandiri, karena anak dipandang sebagai makhluk biologis bukan sebagai makhluk psikologis dan makhluk sosial. Padahal selain pemenuhan kebutuhan fisiologis, anak membutuhkan kasih sayang bagi perkembangan psikis yang sehat seperti halnya vitamin dan protein bagi perkembangan biologisnya. Margareth (dalam Hurlock, 1995). Permasalahan penelitian ini adalah “ Bagaimana gambaran resiliensi pada remaja penderita luka bakar yang berada di panti asuhan?"

\section{METODE}

\section{Partisipan}

Teknik pengambilan sampel yang digunakan adalah teknik bola salju atau berantai (snowball atau chain sampling). Pengambilan sampel dilakukan secara berantai dengan meminta informasi pada orang yang telah diwawancarai atau dihubungi sebelumnya, demikian seterusnya (Poerwandari, 2005). Teknik ini dirasa tepat karena tidak mudah untuk menemukan penderita luka bakar yang tinggal di panti asuhan. Sesuai dengan masalah penelitian, partisipan penelitian ini adalah remaja korban kebakaran yang memiliki luka bakar, dan tinggal di panti asuhan karena kehilangan orang tua dan anggota keluarga akibat kebakaran tersebut. Jumlah partisipan yaitu 1 orang subjek, sesuai dengan pendapat Poerwandari (2005) yang menyatakan bahwa penelitian kualitatif tidak menekankan pada jumlah, tapi berupaya memahami sudut pandang dan konteks subjek penelitian secara mendalam. Satu subjek diharapkan dapat menggambarkan kedalaman konteks dan proses.

\section{Desain}

Metode penelitian yang digunakan dalam penelitian ini adalah metode kualitatif yang secara spesifik tergolong di dalam studi kasus yang bertujuan untuk memperoleh pemahaman yang utuh dan terintegrasi mengenai interrelasi berbagai fakta dan dimensi dari kasus khusus (Poerwandari, 2005). Penelitian ini ditujukan untuk mengetahui dan memahami secara mendalam gambaran resiliensi pada remaja penderita luka bakar yang tinggal di panti asuhan, juga dibutuhkan kegiatan lapangan di mana peneliti dapat memiliki kedekatan dengan individu di mana dalam penelitian ini ialah remaja.

\section{Prosedur}

Prosedur dalam penelitian ini antara lain ialah menyusun pedoman wawancara, setelah itu dilakukan expert judgment pedoman wawancara, dilakukan latihan wawancara dengan orang lain sebelum langsung 
dengan subjek, sebelum wawancara dengan subjek dilakukan tahap terakhir ialah tahap pemeriksaan seperti peralatan apa saja yang harus dibawa pada saat wawancara berlangsung.

\section{Teknik Analisis}

Menurut Poerwandari (2005), langkah-langkah yang dilakukan dalam analisis data antara lain mentraskrip hasil wawancara dalam bentuk verbatim, membaca berkali-kali verbatim untuk mendapatkan kata kunci, kemudian menuliskan kode-kode pada data atau kata kunci yang sudah diperoleh, yang terakhir melakukan intepretasi pemahaman teoritis dan pengambilan kesimpulan.

Dalam penelitian kualitatif, hal penting yang dapat dilakukan untuk meningkatkan generabilitas dan kredibilitas adalah melakukan triangulasi. Patton (dalam Poerwandari, 2007) menyatakan bahwa triangulasi dapat dibedakan atas: 1 . Triangulasi data, 2. Triangulasi pengamat, 3 . Triangulasi teori, 4 . Triangulasi metode. Teknik triangulasi yang digunakan di dalam penelitian ini adalah triangulasi data dengan cara mewawancarai significant other subjek penelitian yaitu dengan melakukan wawancara terhadap ibu asuh di panti asuhan yang bertujuan untuk mengecek ulang hasil wawancara subjek.

\section{ANALISIS \& HASIL}

Berikut ini akan dijabarkan hasil penelitian berdasarkan wawancara dan observasi yang dilakukan penulis.

Tabel 1. Profil Responden Penelitian

\begin{tabular}{ll}
\hline Aspek & Subjek \\
\hline Inisial & $\mathrm{R}$ \\
Usia & 16 \\
Jenis Kelamin & Laki-laki \\
Suku & Jawa \\
Pendidikan Terakhir & SMP (Sekolah Menengah Pertama) \\
Pekerjaan & Pelajar SMA \\
Status & Belum Menikah \\
Anak ke....dari.... & 1 dari 1 saudara (anak tunggal) \\
Waktu peristiwa kebakaran & Agustus 2010 \\
Usia pada saat terjadi peristiwa & 14 \\
Lama menderita luka bakar & 2 tahun \\
\hline
\end{tabular}

$\mathrm{R}$ ialah remaja yang berjenis kelamin laki-laki, yang berusia 16 tahun. $\mathrm{R}$ memiliki bentuk wajah yang oval atau panjang di bagian dagu, dan terdapat lesung pipi di bagian pipi kanan. Juga terlihat di bagian wajah bekas-bekas luka bakar yang berupa kerutan-kerutan di sebagian pipi kiri, telinga kiri yang sudah hampir tidak berbentuk telinga yang sempurna atau melipat ke dalam lubang telinga, hingga ke bagian leher. $\mathrm{R}$ mengalami kerusakan fisik yang cukup parah di bagian telinga, leher, sebagian wajahnya dan kedua jari-jari tangannya. R juga harus kehilangan kedua orang tuanya yang pada saat peristiwa kebakaran karena sedang tertidur pulas. $\mathrm{R}$ sangat terpukul dan hampir putus asa menghadapi peristiwa kebakaran tersebut, karena peristiwa tersebut membuatnya harus hidup sebatang kara dan mengalami penderitaan akibat luka bakar. 
R pun mengalami konflik terkait dengan luka bakarnya tersebut. Kehidupan sosial yang dijalani R sering kali mengalami hambatan, seperti ejekan yang dilontarkan oleh lingkungan dan teman-temannya berkaitan dengan kecacatan fisik R. Hambatan tersebut membuatnya sering merasa bahwa kehidupan yang dijalaninya tidak lagi penuh semangat, antara lain R sering sekali menyendiri, sedikit sulit untuk berkomunikasi, karena $\mathrm{R}$ merasa minder atau tidak percaya diri atas luka bakarnya tersebut. $\mathrm{R}$ sangat berusaha keras untuk bisa melewati kehidupan yang dijalaninya tersebut, $\mathrm{R}$ berusaha untuk tetap ceria dan menjalankan aktivitasnya seperti sedia kala. Hal ini diusahakannya dengan cara, $\mathrm{R}$ tidak terlalu memusingkan pikiran orang lain yang tidak sejalan dengannya. R selalu menanggapi positif segala hal buruk yang ia terima dari lingkungan.

Saat ini R hidup di panti asuhan bersama dengan ibu asuh, dan penghuni panti asuhan. $\mathrm{R}$ merasa bersyukur karena ibu asuh dan penghuni panti asuhan lainnya sangat memperhatikan dan sering menghibur $\mathrm{R}$ di kala R sedih dan ingat pada kedua orangtuanya. $R$ bersekolah di salah satu Sekolah Menengah Atas Negeri di daerah Jakarta Selatan. Setelah tinggal di panti asuhan, R didaftarkan di sekolah tersebut karena salah satu donatur di panti asuhan yang $\mathrm{R}$ tempati ialah pemilik sekolah tersebut, sehingga selama $\mathrm{R}$ bersekolah tidak mengeluarkan begitu banyak dana, dan kebetulan sekolah tersebut tidak jauh dengan panti asuhan yang $\mathrm{R}$ tempati. R menghabiskan waktu di sekolah dari pukul 07.00-14.00 dari hari Senin sampai Jumat, kecuali hari Selasa R pulang dari sekolah pada pukul 16.30 karena mengikuti ekstrakurikuler musik di sekolahnya.

\section{Gambaran Resiliensi}

Gambaran resiliensi R berdasarkan hasil wawancara dan observasi terhadap R dan ibu asuhnya adalah sebagai berikut. Sifat optimis membantu R pada saat fase akut ketika kebakaran terjadi. Dalam perjalanan menuju rumah sakit setelah kebakaran terjadi, $\mathrm{R}$ sempat mendengar pembicaraan yang mengatakan luka $\mathrm{R}$ cukup parah di bagian wajahnya. Pada saat itu $\mathrm{R}$ belum merasakan sakit, yang ada dipikirannya hanyalah keadaan kedua orangtuanya, ia sangat ingin sekali lekas bergegas untuk tetap memastikan keadaan orangtuanya baik-baik saja. Pada akhirnya R menyadari bahwa kedua orangtuanya telah meninggal akibat kebakaran tersebut. Namun R yakin bahwa ada jalan lain yang membuatnya masih bertahan dalam situasi yang berat seperti ini, walaupun jalan lain tersebut belum ada di pikiran R saat itu. Hal ini menunjukkan bahwa R memiliki ciri individu yang optimis, $\mathrm{R}$ masih bisa melihat harapan dalam kondisi yang buruk.

"Sakit pasti kak, cuma harus bertahan lah. "

R memiliki tekad besar untuk sembuh dan beraktivitas seperti sediakala. Demi mencapai keinginan tersebut, $\mathrm{R}$ dengan tekun melakukan usaha-usaha untuk memulihkan fungsi geraknya. Langkah-langkah yang dilakukan $\mathrm{R}$ untuk memulihkan fungsi geraknya adalah melakukan terapi gerak pada wajah rutin setiap hari. Terapi gerak pada wajah yang biasa $\mathrm{R}$ lakukan antara lain, pemijatan pada wajah, peregangan otot-otot seperti mengerut-ngerutkan wajah, memakan permen karet agar otot terlatih lebih lentur, dan mengoleskan minyak zaitun. R melakukannya secara rutin setiap hari tanpa jemu. Dalam hal tersebut ibu asuh sangat berperan penting dalam proses penyembuhan luka bakar R tersebut, ia selalu mengingatkan R agar tidak lupa untuk terapi pada wajah R agar lekas lentur kembali otot-otot wajahnya. R juga terkadang melakukan tai-chi, seni gerak dari China yang berguna untuk beladiri dan kesehatan. Selain itu dapat juga untuk memulihkan fungsi gerak, dan memulihkan trauma R terhadap api.

Sebelum peristiwa kebakaran terjadi $\mathrm{R}$ dinilai sebagai individu yang mudah bergaul dan memiliki banyak teman. Namun setelah peristiwa kebakaran dan harus tinggal di panti asuhan, ibu asuh R merasa bahwa $\mathrm{R}$ berubah menjadi mudah marah dan cepat merasa kesal. Terkadang harus menghadapi masalah dengan teman-temannya. Pemicu masalah yang dialami biasanya berkaitan dengan masalah sehari-hari, seperti bercandaan-bercandaan yang tidak disengaja yang membuat $\mathrm{R}$ tersinggung. 
Pengaturan emosi R yang kurang baik menunjukkan pada awalnya R memiliki pengendalian impuls yang kurang baik. $\mathrm{R}$ cenderung tidak berpikir panjang dalam mengambil keputusan, misalnya saat kesal dengan orang lain ia langsung memutuskan untuk memukul (berkelahi).

Setelah berkelahi biasanya terdapat lebam-lebam di tubuh R. Namun R mengaku tidak pernah menghiraukan luka fisik akibat berkelahi tersebut. Ia berpikir bahwa cedera fisik akibat berkelahi akan lekas pulih, tidak seperti luka bakar yang ada di sebagian wajahnya, yang sangat sulit untuk bisa pulih dan normal seperti dulu.

Setelah hampir 2 tahun memiliki luka bakar, R merasa ada perubahan dalam dirinya ketika menghadapi situasi yang membuatnya kurang nyaman. $R$ mengaku bahwa awal menderita luka bakar biasanya dia sangat mudah marah. Namun kini dia menjadi tidak mudah marah, $\mathrm{R}$ menyadari bahwa tidak ada gunanya dia berkelahi dan setiap $\mathrm{R}$ merasa kesal dengan orang lain, $\mathrm{R}$ berpikir dua kali untuk berkelahi karena kini $\mathrm{R}$ lebih sayang dan hati-hati terhadap tubuhnya. R menjadi lebih banyak pertimbangan dalam menyelesaikan masalah. R merasa bahwa lebih baik fokus untuk menyembuhkan luka bakar yang cukup berat dideritanya sehingga tidak ada guna $\mathrm{R}$ menambah luka bakar lagi karena mengurusi hal-hal sepele.

"Sayang banget kak hidup aku cuma buat berantem, udah susah payah gak mau lukain badan lagi, luka bakar ini aja udah setengah ampun ngobatinnya, dan sakitnya ampun-ampun, masa masalah kecil aja harus ribut dan ngelukain diri lagi “.

Menurut Reivich \& Shatte (2002) hal ini menandakan bahwa R mengalami peningkatan kemampuan mengendalikan impuls yang meliputi kemampuan mengontrol dorongan, dan tidak mengikuti pemikiran pertamanya saat berespon mengenai suatu hal, melainkan mempertimbangkannya kembali. Hal ini terjadi karena ia ingin terfokus hanya kepada keadaan luka bakarnya tersebut. $\mathrm{R}$ tidak ingin menambah luka ditubuhnya akibat perkelahian tersebut.

Menurut ibu asuh R, R menjadi lebih sabar dan lebih tenang dalam merespon masalah-masalah yang terjadi, terutama dalam mengekspresikan kemarahan. Perlahan-lahan emosi $\mathrm{R}$ dapat diatasi dengan baik. $\mathrm{R}$ yang dulu awal-awal tinggal di panti asuhan dan sudah memiliki luka bakar, emosi nya masih sangat terlihat jelas, gampang sekali terpancing, namun saat ini emosi tersebut sudah dapat dikendalikannya.

"Kalo dulu mba awal-awal sering banget berantem dan tersinggungan, tapi saya gak merasa kewalahan

kok, saya ingin dia seperti anak lainnya, yang tidak beda apa pun"

"Kayak lebih legowo gitu mba.."

Hal ini menunjukkan R mengalami peningkatan dalam hal regulasi emosi yang baik, yang menurut Reivich \& Shatte (2002) tercermin dari kemampuan untuk mampu mengendalikan emosi, perhatian, dan tingkah laku. Peningkatan regulasi emosi ini terjadi karena dukungan dari lingkungan terutama ibu asuhnya yang selalu membimbingnya, dengan selalu berusaha mengarahkan dan menenangkan jika emosi R sedang terpancing atau memuncak.

$\mathrm{R}$ juga cenderung lebih santai merespon pandangan aneh orang lain saat dirinya sedang berada di tempat umum. Hal ini terjadi karena $\mathrm{R}$ sudah memprediksikan sebelumnya bahwa ia pasti akan menjadi pusat perhatian karena bekas lukanya.

"aku sekarang udah rada gak peduli, karena udah sangat sering orang ngeliatin aku sebelah mata, aku emang udah prediksi, bakalan dicibir orang lain seperti orang cacat..tapi ya udahlah..bodo, hehe..”

Saat ini jika ada orang menghindar atau menjauh darinya, $R$ mencoba untuk memahami hal tersebut. $R$ mencoba menganggapnya sebagai hal wajar karena mungkin bekas luka bakarnya seperti penyakit menular. $\mathrm{R}$ juga pernah melihat ada seorang wanita berusia sekitar 35 tahun yang memegang perutnya dan berkata 
“amit-amit jabang bayi” ketika melihat R. Meskipun tersinggung, R berusaha menganggap wajar reaksi wanita tersebut karena ia tidak mau keturunannya nanti memiliki wajah atau mengalami hal seperti yang dialami R.

"Sekarang gini yaa kak..waktu itu ada wanita, terus ngeliat aku gitu sambil megang-megang perutnya terus bilang amit-amit jabang bayi..perasaan aku kaya gimana gitu kak..yaa tapi wajar lah, mana ada sih orang yang mau keturunannya nanti ngalamin kaya aku, muka kerutan begini..."

Kejadian kebakaran yang berakibat hilangnya nyawa kedua orangtuanya, membuat $\mathrm{R}$ kerap merasa sedih mengingat orangtuanya. Terutama tiap kali tiba hari ulang tahun mendiang ayah dan ibunya. Namun $\mathrm{R}$ tidak membiarkan kesedihannya berlarut-larut dengan cara mengalihkan fokusnya ke hal lain seperti bermain gitar dan sesekali mengobrol dengan teman.

"Setiap tahun tuh aku pasti inget ulang tahun papa mama, karena ulang tahunnya gak beda jauh, cuma beda sebulan aja, jadi yah tiap tahun selalu sedih, sempet keinget yang dulu-dulu"

Saat sedang sedih R terkadang juga lebih memilih untuk berdiam diri di kamarnya.

"kalo sedih yaa... aku diam diri di kamar, sambil cerita sama papa mama di surga , maksudnya sholat, tapi lebih banyak diem sih"

Dalam hal mengekspresikan emosi positif, seperti emosi senang, $\mathrm{R}$ biasanya mengungkapkannya kepada orang-orang terdekat. Jika sedang senang R suka mengajak orang-orang terdekatnya bermain bersama, berpergian ke tempat-tempat yang menyenangkan, seperti bermain bola di lapangan bola dekat dengan panti asuhan atau dengan bernyanyi dan bermain gitar.

"kalo seneng yaa paling aku nyanyi-nyanyi sambil main gitar aja.."

$\mathrm{R}$ adalah individu yang optimis. $\mathrm{R}$ cenderung berpikir positif terhadap hidupnya dan hal-hal yang ia lakukan. R memiliki cita-cita untuk dapat memiliki band besar dan ternama, agar dapat terkenal dan dapat memenuhi kebutuhan hidupnya secara mandiri. Sesuai dengan pemikiran remaja seusianya, dapat dikatakan pikiran R sudah terkonsep untuk kehidupannya di masa yang akan datang. R tidak ingin berlarut-larut dalam kesedihan, terkait dengan kehilangan orangtua dan luka bakar yang dideritanya, ia juga tidak mau selamanya merepotkan ibu asuh yang selama ini sudah merawatnya. $\mathrm{R}$ yakin kehidupan ia nantinya tidak selamanya berada di panti asuhan, setelah $\mathrm{R}$ telah mampu hidup mapan dengan pekerjaan yang tetap. Kini fokus $\mathrm{R}$ ialah bersekolah dengan baik dan rajin belajar. $\mathrm{R}$ yakin tujuan hidupnya akan tercapai. Bagi $\mathrm{R}$ peristiwa kebakaran yang menyebabkan luka bakar dan kehilangan orangtuanya, merupakan pemicu dirinya untuk berjuang demi masa depan.

"Yaa itu kak hidup yang aku mau, aku nanti akan hidup mandiri dan udah bisa ngasilin uang sendiri, aku gak mau jadi bahan kasianan orang lain kak, aku gak mau ketergantungan terus sama ibu. “

$R$ yakin ia mampu meraih semua cita-citanya tersebut bila dapat dukungan dan restu ibu asuhnya, serta tetap rajin berlatih bermain musik. Kecintaan $\mathrm{R}$ akan gitar, membuatnya memiliki tekad besar untuk bisa bermain gitar lagi, walaupun harus melalui proses yang menyakitkan, $\mathrm{R}$ tidak pernah menyerah untuk meraih apa yang ia inginkan. R tetap memiliki harapan walau dalam kondisi sulit, sesuai dengan ciri individu optimis dari Reivich \& Shatte (2002), yaitu individu yang percaya bahwa suatu hal dapat berubah menjadi lebih baik. Mereka memiliki harapan untuk masa depan dan percaya bahwa mereka dapat mengontrol arah tujuan hidup mereka.

Dalam usahanya berlatih main gitar lagi, R mengalami proses yang menyakitkan, dan lukanya pun kerap kembali mengeluarkan darah, namun $\mathrm{R}$ tidak berhenti berlatih, ia mengulanginya lagi. Bagi $\mathrm{R}$ hal tersebut adalah proses yang memang harus dilewati untuk bisa bermain gitar kembali. Hal ini menunjukan bahwa self-efficacy R berkembang baik, menurut Reivich \& Shatte (2002) individu yang memiliki selfefficacy yang tinggi tetap berkomitmen untuk mengatasi masalah dan tidak menyerah bahkan saat mereka 
menemukan bahwa solusi yang ditetapkan di awal tidak berhasil, hal ini terlihat dari $\mathrm{R}$ yang tidak berhenti main gitar meskipun jari-jari tangannya yang kaku kerap mengeluarkan darah.

"Aku paksain main gitar kak, sakit banget, sampe berdarah gitu, tapi mau sampe kapan aku berdiam diri tanpa aktivitas gini, dan ga ada hal yang aku bisa, jadi harus banget bisa main gitar lagi.”.

$\mathrm{R}$ ingin merasa tetap berguna dengan mencoba membantu siapa pun yang ia anggap butuh pertolongan. Namun keinginan ini masih terhalang oleh keterbatasan fisik dan anggapan lingkungan yang masih kurang mempercayai kemampuannya.

“ Kemauan aku yaa tiga itu aja sih kak, aku hobi banget sama musik, main band gitu, terutama yaa main gitar, sekarang udah begini mah susah kak, leher aku juga kak belom bisa gerak-gerak banget, ngendarain motor sih bisa sebenernya, cuma yaa kalo pake helm itu masih sedikit sakit kalo kena kulit, kalo bantu orang juga kadang suka dibilang gak bisa apa-apa, jadi serba salah.."

Setelah kondisi fisiknya menjadi tidak sempurna karena luka bakar, R merasa banyak orang tidak mempercayainya dalam hal mengerjakan sesuatu atau pekerjaan. $\mathrm{R}$ merasa orang lain tidak yakin bahwa ia mampu menyelesaikan pekerjaannya dengan baik karena keterbatasan fisiknya. $\mathrm{R}$ menyimpulkan demikian karena tawaran akan mengerjakan tugas kelompok dari sekolah, yang teman-teman $\mathrm{R}$ tidak pernah menyerahkan dan mempercayai agar $\mathrm{R}$ saja yang mengerjakan tugas tersebut, dengan alasan kasihan kepada $\mathrm{R}$, dan menyuruh $\mathrm{R}$ agar mengerjakan tugas lainnya saja. Namun tidak demikian halnya dengan di panti asuhan yang $\mathrm{R}$ tempati saat ini. Ibu asuh $\mathrm{R}$ menerapkan kedisplinan untuk semua penghuni panti asuhan, tak terkecuali R, R dianggap bisa melakukan hal-hal yang bisa dilakukan semua orang, contohnya $\mathrm{R}$ juga dilibatkan dengan kegiatan kerja bakti di lingkungan panti asuhan, $\mathrm{R}$ melakukan pekerjaan yang sama dengan penghuni panti asuhan tersebut, seperti memotong rumput, mencuci motor, dll.

“Misalnya kayak tugas kelompok sekolah aja, aku suka gak dilibatin dalam ngerjain tugas itu, yaa nama aku sih dimasukin kak dalam kelompok, cuma yaa itu, anak-anak suka ga yakin aja aku bakal ngerjain tugas itu, kadang nanya nya gini "bisa gak lu” itu tuh yang kepikiran sama aku kak, padahal aku masih mampu. Kalo di panti mah ngerjain apa aja kak, ga dibeda-bedain sama ibu, kalo kerja bakti yaa harus ikut"

Perlakuan yang sama dan kepercayaan terhadap kemampuan R dari panti asuhan meningkatkan selfefficacy R. R menjadi terbiasa menjadi penyumbang ide dan penyusun konsep dalam sebuah kelompok atau panitia-panitia acara tersebut, yaitu dalam acara-acara yang biasa diadakan oleh panti asuhan, seperti acara kemerdekaan Republik Indonesia, acara hari ulang tahun panti asuhan, dll. Menurut Reivich \& Shatte (2002), salah satu karakteristik individu yang memiliki self-efficacy yang baik, individu biasanya sering ditujukan sebagai pemimpin atau orang yang paling berpengaruh di suatu kelompok.

"Hmm, biasanya ide itu muncul dari ibu sama temen-temen di Panti kak, yaa itu sih yang kadang bikin aku termotivasi, bikin percaya diri."

$\mathrm{R}$ mengaku senang membantu teman-teman dan orang terdekatnya jika mereka membutuhkan bantuan, walaupun bagi $\mathrm{R}$ bantuan yang diberikan tidak besar. Hal ini membuat $\mathrm{R}$ mudah disenangi orang lain.

Namun selain itu, menurut ibu asuh $\mathrm{R}, \mathrm{R}$ masih mengalami krisis kepercayaan diri yang tidak diungkapkan oleh $\mathrm{R}$. Terlihat dari perilaku $\mathrm{R}$ yang tidak biasa seperti enggan sekali menemui tamu yang berkunjung ke panti asuhan, sekalinya bertemu ia akan berpenampilan yang tidak seperti biasa, atau berpenampilan rapih sekali.

"Sebenernya dia sekarang jadi sedikit minder, walaupun dia juga ga bilang langsung ke saya, tapi sebenernya keliatan aja, kaya kalo dia lagi ketemu tamu yang datang ke Panti, saya ngeliat gerakgeriknya yang kurang nyaman gitu." 
Masih menurut ibu asuhnya, R sering memiliki kecenderungan berpikir negatif terhadap orang lain, $\mathrm{R}$ sering menganggap orang lain bermaksud buruk padanya, meskipun sebenarnya orang tersebut tidak bermaksud buruk. Dalam hal ini R terlihat mempercayai pikiran impulsifnya. R menyangka seseorang bermaksud buruk padanya, padahal hal itu belum tentu benar.

“Emang sih mba, setelah hampir 2 tahun ini punya luka bakar, dia udah jarang sekali berantem, main pukul-pukulan gitu, tapi dia jadi sensian gitu sama orang, bilangnya orang mau jahatin dia terus, padahal sih belum tentu mba"

Sejak pertengahan tahun 2011, R aktif dalam sebuah komunitas di jejaring sosial yang disebut Yayasan Peduli Luka Bakar, yang merupakan media sumber informasi mengenai segala sesuatu mengenai luka bakar dan peristiwa kebakaran. Aktivitas komunitas di jejaring sosial tersebut adalah untuk berbagi dan saling memotivasi sesama korban luka bakar, serta media yang mencari bantuan dana untuk korban luka bakar yang tidak mampu.

"Ya awalnya iseng-iseng sih kak, soalnya aku ngerasain banget gimana punya luka bakar, aku mau sharing aja sama orang-orang di luar sana yang ngalamin kaya aku juga, kadang termotivasi juga dari komunitas di internet itu kak, yaudah saling bantu aja lah"

Dengan $\mathrm{R}$ bergabung dalam komunitas tersebut, walaupun hanya jejaring sosial, membuat $\mathrm{R}$ merasa termotivasi untuk tetap bertahan hidup dan mengembangkan kemampuan empati nya dengan ingin berbagi dan membantu sesama korban luka bakar.

Dibalik peristiwa kebakaran tersebut, $\mathrm{R}$ merasa beruntung karena masih diberi kesempatan untuk hidup. Selain itu, hal positif yang dirasakan $\mathrm{R}$ setelah memiliki luka bakar adalah $\mathrm{R}$ menjadi seorang remaja yang tegar walau rintangan yang dihadapinya cukup berat, $R$ menjadi jauh lebih menghargai orang lain, dan merasa membutuhkan orang lain terutama ibu asuhnya tersebut, $\mathrm{R}$ juga merasa hidup saat ini penuh dengan kebersamaan dan berbagi dengan orang lain terutama dengan penghuni panti asuhan. Individu yang resilien adalah individu yang mampu meningkatkan aspek positif dari kehidupan, $\mathrm{R}$ memenuhi indikator tersebut. R sebelumnya tidak begitu senang dengan kebersamaan dan berbagi, karena $\mathrm{R}$ ialah anak tunggal dan jelas tidak memiliki saudara, ia hanya tinggal dengan kedua orangtua nya, sedangkan saat ini di panti asuhan, $\mathrm{R}$ dituntut untuk saling bertoleransi dengan sesama, seperti dalam berbagi makanan pun $\mathrm{R}$ harus memikirkan kebersamaan penghuni panti asuhan lainnya. Kini R menyadari bahwa kebersamaan dan saling berbagi itu sangat berarti dalam proses penyesuaiannya.

R menganggap peristiwa kebakaran yang dialaminya sebagai sebuah musibah. Hal tersebut mungkin karena ketidak sengajaan kedua orangtua nya dalam menggunakan listrik di kehidupan sehari-hari. R memiliki fleksibilitas dalam gaya berpikir menganalisis sebab dari terjadinya peristiwa tragis. R memiliki gaya berpikir "bukan-saya" (Reivich \& Shatte, 2002). Gaya berpikir ini membuat R tetap dapat menjaga self-esteem nya dan tidak terus-menerus menyalahkan diri sendiri.

Bagi R, setelah peristiwa kebakaran, hal yang paling menyakitkan adalah kepergian kedua orangtuanya. Namun ada pula hal yang membahagiakan bagi $R$, yaitu kehidupan yang penuh kebersamaan saat ini di dalam panti asuhan, motivasi R timbul karena banyak sekali pelajaran yang dapat membuatnya terus berkembang dan maju dari panti asuhan tersebut, dan karena bimbingan dari ibu asuhnya. $\mathrm{R}$ memiliki gaya berpikir tidakmeluas. Gaya berpikir tidak-meluas ini membuat $\mathrm{R}$ melihat bahwa tidak seluruh aspek hidupnya menjadi buruk karena luka bakar.

"Aku liat sisi positifnya kak, kebersamaan ini sangat membuat aku nyaman, aku gak mau berlarutlarut dari kesedihan.“ 
Seperti yang dituliskan sebelumnya, kematian orangtua $\mathrm{R}$ adalah peristiwa yang membuat $\mathrm{R}$ sangat terpukul, $\mathrm{R}$ sangat dekat dengan kedua orangtuanya. $\mathrm{R}$ pun tidak menyangka kedua orangtuanya akan meninggal karena peristiwa kebakaran tersebut. Pada awalnya $R$ sering menangis ketika ingat dengan kedua orangtuanya, R pun sering mengunjungi makam kedua orangtuanya. Namun $\mathrm{R}$ sadar bahwa kesedihan tidak perlu berlarut-larut, dukungan dari ibu asuh sangat berharga bagi R. R berusaha mengalihkan kesedihannya pada pikiran-pikiran positif. $\mathrm{R}$ memiliki gaya berpikir tidak-selalu. $\mathrm{R}$ melihat masalah dan kesedihan tidak terus-menerus dan akan berlalu.

“Pokoknya kalo aku sedih buru-buru deh alihin pikiran, buru-buru main gitar, nyanyi-nyanyi sendiri,

karena aku juga gak mau buat ibu kepikiran aku terus kak, ibu suka merhatiin aku soalnya, gak perlu deh sedih-sedih terus, gak akan maju-maju.“

Faktor risiko adalah faktor yang berasal dari individu atau lingkungan yang meningkatkan munculnya dampak negatif (Kirby \& Fraser dalam Small \& Memmo, 2004). Faktor risiko dari dalam diri R yang dapat menghambat resiliensi adalah pengendalian impuls yang kurang baik terutama pada saat awal tinggal di panti asuhan. $R$ cenderung mudah kesal dan sering berkelahi. Faktor dari lingkungan keluarga yang mungkin dapat menghambat proses penyesuaian $\mathrm{R}$ adalah kematian kedua orangtuanya. Ia memiliki firasat seperti tidak tenang, gelisah memikirkan keadaan orangtuanya.

Hal yang menjadi hambatan setelah R memiliki luka bakar adalah kesulitannya untuk dapat meyakinkan lingkungan di luar panti asuhan, seperti sekolah agar mempercayainya melakukan segala sesuatu, dan tidak meremehkannya. Adanya rasa penolakan dari lingkungan merupakan salah satu faktor resiko penderita luka bakar (Campbell, 1976, Carvajal, 1990, El Hamaoui, 2002, Stoddard \& O’Connell, 1983). Salah satu respon negatif yang mungkin diterima oleh penderita luka bakar adalah diskriminasi dalam suatu pekerjaan (Beuf, 1990, Macgregor, 1990, Pruzinsky \& Doctor, 1994 dalam Lawrence, dkk, 2007).

Menurut Masten \& Coatsworth (1998) beberapa faktor protektif dapat berasal dari kualitas individu dan lingkungan yang diasosiasikan dengan kompetensi atau fungsi psikososial yang lebih baik selama menghadapi masalah. Faktor protektif ini dapat meningkatkan resiliensi pada diri individu. Pada subjek $\mathrm{R}$, faktor-faktor protektif yang ditemukan adalah keluarga saat ini di panti asuhan, tim medis, media sosial dan kualitas dirinya. Hal-hal tersebut membantu $\mathrm{R}$ dalam proses penyesuaian dirinya terhadap luka bakar.

Saat pulang ke rumah barunya waktu itu yaitu panti asuhan setelah perawatan medis di rumah sakit, $\mathrm{R}$ merasa lebih nyaman di rumahnya tersebut. Ibu asuh dan $\mathrm{D}$ sahabatnya yang setia menggantikan perban lukanya setiap 2 hari sekali. $\mathrm{R}$ sangat termotivasi untuk lekas sembuh dan beraktivitas normal kembali. Dan jika ada kegiatan-kegiatan yang ada di panti asuhan, seperti ada beberapa donatur atau dermawan yang mengadakan acara pengajian di panti asuhan, $\mathrm{R}$ dilibatkan dalam acara tersebut, seperti membantu memberes-bereskan bangku untuk acara, menyiapkan perlengkapan untuk acara, sehingga $\mathrm{R}$ merasa hidup yang dijalaninya lebih berguna.

Masa perawatan medis adalah masa-masa sulit yang harus dilalui R. Biaya yang dibutuhkan untuk menyembuhkan luka bakar R tersebut sangat besar, walaupun banyak sekali yang membantunya, salah satunya para tetangga di rumah $R$ yang dulu, para dermawan yang mengetahui keberadaan $R$ di panti asuhan, dll. Orangtua $\mathrm{R}$ semasa hidupnya adalah seorang yang ramah dan mempunyai banyak teman, sehingga di masa-masa sulit banyak sekali orang-orang yang membantu dalam hal materi maupun pengetahuan mengenai penyembuhan luka bakar. Hal ini menunjukan bahwa lingkungan sosial di panti asuhan R juga mempengaruhi proses penyesuaian $\mathrm{R}$. 
Tim medis merupakan faktor protektif yang membantu penyesuaian $\mathrm{R}$ saat dirawat di rumah sakit. Selama 3 bulan menjalani perawatan di rumah sakit, R tidak merasa begitu kesepian karena ditemani sustersuster yang ramah dan humoris.

"Iyaa kak, suster-suster baik-baik, urusin aku waktu di rumah sakit, Alhamdulillah lah kak. "

Kualitas diri merupakan faktor protektif dalam resiliensi. Karakter positif yang dimiliki oleh $\mathrm{R}$ sejak sebelum memiliki luka bakar adalah kepercayaan diri yang tinggi (self-esteem). Ini membantu $\mathrm{R}$ saat menghadapi situasi di mana orang lain memandangnya dengan aneh, takut, atau jijik. Kepercayaan diri pun meningkatkan self-efficacy nya, bahwa ia selalu dapat mencapai apa yang dia inginkan seperti dapat hidup mandiri di kemudian hari, dapat bermain gitar dan memiliki sebuah band, serta mampu menyelesaikan segala sesuatunya dengan baik. Kepercayaan diri menunjukkan bahwa $\mathrm{R}$ memiliki self-esteem yang positif. $\mathrm{R}$ juga memiliki karakter positif cerdas. Hal ini membantu $\mathrm{R}$ dalam mencari solusi atas masalah-masalahnya. $\mathrm{R}$ memiliki jiwa kompetensi yang positif, di mana ia selalu menganggapi hal positif orang lain terhadapnya. Karakter positif ini membantu $\mathrm{R}$ untuk menyelesaikan tiap pekerjaan dengan baik walaupun orang lain tidak yakin akan kemampuannya. $\mathrm{R}$ pun juga tidak pernah memilih teman dalam bergaul. Hal ini membangun kemampuan reaching out pada diri R. Individu yang reaching out adalah individu yang selalu ingin mengenal orang lain dan lingkungan yang baru. Memiliki teman yang banyak membuat $\mathrm{R}$ mendapat banyak dukungan positif dalam proses penyesuaiannya.

Sesuai dengan diungkapkan Friborg, Sorlie, and Rosenvinge (2005 dalam Schultz, Rodity \& Gillette, 2009), mengenai faktor yang dapat meningkatkan resiliensi, R memenuhi karakter self-esteem yang positif, cerdas, dan memiliki kemampuan sosialisasi dan komunikasi yang baik, serta mendapat dukungan keluarga di Panti Asuhan dan kedekatan dengan ibu asuhnya.

\section{DISKUSI}

Sumbangan penelitian ini ialah penelitian ini dapat dijadikan acuan untuk penelitian lain yang ingin meneliti tentang remaja, penderita luka bakar, ataupun mengenai panti asuhan, karena hasil yang didapatkan pada subjek dalam penelitian ini cukup baik, subjek mampu melewati tantangan hidup dengan mengembangkan beberapa kemampuan resiliensi.

Margareth (dalam Hurlock, 1995) dalam laporan hasil penelitiannya menyimpulkan bahwa perawatan anak di yayasan sangat tidak baik, karena anak dipandang sebagai makhluk biologis bukan sebagai makhluk psikologis dan makhluk sosial. Padahal selain pemenuhan kebutuhan fisiologis, anak membutuhkan kasih sayang bagi perkembangan psikis yang sehat seperti halnya vitamin dan protein bagi perkembangan biologisnya,dalam penelitian tersebut mengatakan kehidupan di panti asuhan, anak-anak tidak mendapatkan lingkungan yang sehat bagi perkembangan psikologisnya. Namun pada penelitian ini tidak ditemukan hal yang negatif seperti yang disimpulkan pada penelitian tersebut. Dalam penelitian ini justru Panti Asuhan lah yang memegang peranan penting dalam perkembangan resiliensi subjek, karena subjek dipandang makhluk sosial yang sama dengan penghuni Panti Asuhan lain, yang harus dijaga dan diperhatikan kehidupannya. Di Panti Asuhan lah subjek mendapatkan kehidupan yang layak, walaupun subjek memiliki kekurangan fisik, namun tidak ada perlakuan yang berbeda dari ibu asuh dan para pengasuh lainnya di sana, sehingga subjek merasa keberadaannya diakui oleh Panti Asuhan tersebut. 
Berdasarkan penelitian Fauerbach, Powers, Cruse, Daniels \& Stevens (2000 dalam Fauerbach dkk. 2002), ditemukan bahwa remaja penderita luka bakar, cenderung mengalami hal-hal yang tidak terjadi pada remaja lain, seperti PTSD (post traumatic disorder), masalah self-esteem, respon negatif dari lingkungan, aktivitas yang terbatas karena kerusakan fisik. Pada subjek masalah yang ditemukan lebih kepada respon negatif dari lingkungan dan aktivitas yang terbatas karena kerusakan fisik. Respon negatif dari lingkungan dapat diatasi subjek dengan kemampuan pengendalian impuls \& regulasi emosi yang baik, subjek yang dahulu mudah sekali terpancing dengan respon negatif dari lingkungan, namun sekarang ini subjek lebih santai dalam merespon tanggapan lingkungan yang negatif terhadapnya, hal tersebut karena subjek hanya memfokuskan dirinya dan meyakinkan dirinya agar tidak terpancing dengan tanggapan lingkungan tersebut. Subjek juga memiliki rasa empati terhadap lingkungan, sehingga ia hanya fokus dan peduli terhadap lingkungan yang merespon dirinya dengan positif, seperti lingkungan di jejaring sosial. Sedangkan aktivitas yang terbatas karena kerusakan fisik dapat diatasi subjek dengan kemampuan self-efficacy yang baik, subjek sangat yakin bahwa dirinya dapat hidup mandiri dan lebih baik dari sekarang ini, hal tersebut yang membuat subjek dapat melakukan segala sesuatu walaupun aktivitasnya terbatas. Sikap optimis subjek juga sangat berpengaruh dalam mengatasi aktivitasnya yang terbatas, subjek cenderung berpikir positif terhadap hidupnya dan hal-hal yang ia lakukan, sehingga untuk mencapai apa yang subjek inginkan dapat terpenuhi. Selain itu, subjek juga memiliki kemampuan reaching out, karena subjek juga dapat berkompromi dan menyesuaikan diri dengan ketakutan-ketakutan yang terjadi dalam segala aktivitas yang subjek lakukan. Subjek tidak takut untuk mencoba hal baru yang berkaitan dengan aktivitas yang terbatas tersebut, seperti mencoba untuk mengendarai sebuah motor yang setelah luka bakar mempersulit subjek untuk bisa mengendarai motor.

Gaya menjelaskan (explanatory style) yang ditemukan di dalam penelitian ini sejalan dengan pendapat Reivich dan Shatte (2002) yang mengungkapkan apabila individu mempersepsikan kejadian selalu disebabkan oleh dirinya (internal), self-esteem nya akan jatuh dan akan terus-menerus menyalahkan dirinya mengenai masalah yang terjadi, lalu individu yang berpikir bahwa penyebab suatu peristiwa adalah bukan dirinya yang menyebabkan suatu kejadian, maka individu tersebut akan memiliki self-esteem yang baik dan tidak menyalahkan dirinya sendiri. Hal ini dapat didukung oleh faktor protektif dan kemampuan reaching out individu, yaitu mampu meningkatkan aspek positif dalam kehidupan.

Self-esteem pada diri subjek, subjek menunjukkan kepercayaan diri yang positif. Hal tersebut membantu subjek saat menghadapi situasi di mana orang lain memandangnya dengan aneh, takut atau jijik. Namun subjek tetap menanggapinya dengan positif. Dengan hal seperti itu, subjek lebih memerhatikan penampilan dirinya seperti dalam berbusana jauh lebih rapih atau menggunakan wangi-wangian untuk tubuh (parfum) agar terlihat lebih elok atau baik, agar orang lain tetap menganggapnya seperti orang biasa lainnya, walaupun luka bakar di wajah dan jari-jari tangannya tidak bisa ditutupi, dengan subjek lebih mementingkan penampilannya, mungkin orang lain akan melihat seperti orang normal lainnya. Namun hal tersebut dianggap oleh ibu asuh subjek sebagai bentuk ketidakpercayaan dalam diri subjek.

Ronawulan (2008) mengatakan bahwa kondisi-kondisi yang merusak permukaan tubuh seperti luka bakar, menimbulkan gangguan dalam citra tubuh seseorang. Namun peneliti tidak menemukan masalah yang berarti yang berhubungan dengan citra tubuh pada subjek penelitian ini. Citra tubuh yang dimiliki oleh penderita luka bakar dalam penelitian ini tidak mempengaruhi kemampuan sosialisasi dan komunikasi subjek, serta tidak menjadi hambatan yang berarti dalam proses resiliensi. Hal tersebut terjadi karena subjek berpikir kalau peristiwa yang terjadi padanya ialah hanya sebuah musibah, dan perjalanan hidup yang harus ia lalui yang membuat subjek yakin dapat melaluinya dengan cara apa pun, sehingga subjek tidak terfokus pada citra diri atau penampilan dirinya. 


\section{SIMPULAN \& SARAN}

\section{Simpulan}

Simpulan dari penelitian ini berdasarkan ketujuh dimensi resiliensi dan faktor yang mempengaruhi resiliensi subjek adalah dalam hal regulasi emosi, subjek terlihat sudah mengalami peningkatan. Dalam hal emosi positif, peningkatan yang terjadi ialah subjek cenderung lebih santai ketika merespon pandangan orang lain yang negatif terhadapnya, subjek tidak tersulut oleh emosi dari lingkungan tersebut. Hal itu terjadi karena potensi dalam diri subjek yang baik dan dukungan dari ibu asuh juga berperan dalam hal regulasi emosi ini. Sedangkan dalam hal pengendalian impuls, terlihat subjek mengalami peningkatan dibandingkan sebelum memiliki luka bakar. Peningkatan ini terjadi karena subjek lebih memfokuskan diri pada kehidupannya, dan cenderung berpikiran tidak ada guna memikirkan orang lain yang berpikiran negatif terhadapnya, sehingga subjek mampu mengendalikan emosinya tersebut akibat dorongan dari dalam dirinya.

Terkait dengan dimensi optimisme, terlihat bahwa optimisme subjek tetap stabil semenjak belum memiliki luka bakar maupun setelah memiliki luka bakar. Subjek sangat optimis dalam hal keyakinannya untuk pencapaian harapan di masa depan. Subjek terlihat cukup yakin akan cita-citanya yaitu memiliki sebuah band ternama, sehingga subjek dapat hidup mandiri di kehidupannya kelak. Self-efficacy subjek juga terlihat cukup baik. Hal ini terlihat dari komitmen subjek untuk tidak menyerah dalam mencapai suatu usaha, misalnya ia sangat yakin untuk dapat bisa bermain gitar kembali, apa pun itu halangannya. Saat ini, subjek juga terlihat sudah memiliki rasa empati yang cukup baik. Hal ini terlihat dari subjek tergabung dalam sebuah organisasi di jejaring sosial, yang mengurusi segala hal tentang luka bakar, hal tersebut menunjukkan subjek memiliki keperdulian terhadap orang lain yang mengalami hal yang sama dengannya.

Terkait dengan kemampuan reaching out, subjek cukup mampu mengembangkan kemampuankemampuan positif dalam diri subjek. Subjek dapat berkompromi dan meyakinkan dirinya dalam sesuatu hal, dan ingin mencoba apa pun untuk kebaikan dirinya, misalnya subjek berani melawan ketakutannya untuk tinggal di Panti Asuhan, yang awalnya subjek tidak berkenan untuk tinggal di Panti Asuhan, namun saat ini subjek dapat beradaptasi dengan baik di lingkungan Panti Asuhan, sehingga subjek mampu mengembangkan kemampuan dalam dirinya tersebut. Pada kemampuan analisis kausal, terdiri dari 3 gaya menjelaskan (explanatory style) seseorang yaitu "Saya-Selalu-Semua," "Bukan-Saya," Tidak Selalu-Tidak Semua." Pada diri subjek terlihat kecenderungan untuk berpikir dengan gaya "Bukan-Saya." Hal ini terlihat dari peristiwa kebakaran yang menimpa dirinya dan orang tuanya subjek, yang subjek anggap hanya sebagai musibah, sehingga subjek tidak terus-menerus menyalahkan dirinya. Subjek juga memiliki fleksibilitas dalam berpikir mengenai penyebab kejadian tersebut, ia meresponnya dengan tenang dan tetap menanggapi kejadian tersebut dengan positif.

Berdasarkan faktor risiko (faktor yang menghambat) remaja penderita luka bakar yang tinggal di Panti Asuhan untuk dapat mengembangkan kemampuannya sehari-hari adalah kemampuan pengendalian impuls yang kurang baik terutama saat awal tinggal di Panti Asuhan. Hal ini tercermin dari kecenderungan subjek yang mudah kesal dan sering berkelahi bila mendapat ejekan dari lingkungan. Faktor dari lingkungan, yang dapat menghambat subjek adalah sikap penolakan dari lingkungan, karena kurang percaya terhadap kemampuannya dalam menyelesaikan pekerjaan. Faktor risiko yang seperti itulah yang sering dialami oleh penderita luka bakar, sehingga penderita luka bakar mengalami diskriminasi dari lingkungan. Sedangkan faktor protektif dalam diri subjek adalah ibu asuh yang selalu mendukung dan memberi perhatian untuk 
kesembuhan luka bakar subjek. Tim medis juga termasuk dalam faktor protektif yang membuat subjek dapat bertahan, hal itu karena perawatan medis secara intensif yang dilakukan oleh dokter dan suster yang selalu menjaganya. Media sosial juga dapat memotivasi subjek dalam mengatasi luka bakarnya, subjek sering kali bertukar pikiran dengan teman-temannya yang tergabung dalam jejaring sosial penderita luka bakar tersebut. Berdasarkan kualitas diri subjek yang sangat berperan untuk kelangsungan hidup yang dijalaninya adalah subjek mampu meyakinkan dirinya sendiri untuk dapat melewati setiap masalah (self-efficacy). Hal tersebut dapat membantu subjek dalam proses penyesuaian dirinya terhadap luka bakar.

\section{Saran}

Saran-saran yang diajukan dalam penelitian ini adalah sebagai berikut:

1. Sebaiknya diperbanyak penelitian luka bakar di Indonesia karena frekuensi peristiwa kebakaran di Indonesia cukup tinggi dan menurut penelitian-penelitian di luar negeri, luka bakar memberi banyak pengaruh negatif pada kondisi psikologis yang mengalaminya. Penelitian yang lebih lanjut diharapkan memperoleh gambaran dari hal-hal berikut ini:

2. Resiliensi pada usia anak-anak atau dewasa yang menderita luka bakar. Hal ini disarankan mengingat peristiwa yang menyebabkan luka bakar terjadi tanpa mengenal usia.

3. Gambaran penerimaan lingkungan kerja terhadap penderita luka bakar, terutama di instansi, perusahaan, atau lembaga yang memungkinkan penderita luka bakar berinteraksi dengan banyak orang. Peneliti khawatir banyak kasus diskriminasi pekerjaan terhadap pendeita luka bakar dan atau orang yang memiliki keterbatasan fisik lainnya yang terselubung dan tidak terselesaikan. Aspek yang mungkin diteliti antara lain:social support dan persepsi sosial di lingkungan kerja.

4. Peneliti menyarankan instansi-instansi memberikan kesempatan bagi pegawainya yang memiliki ketidaksempurnaan atau cacat fisik untuk tetap terlibat dalam kegiatan-kegiatan yang memang memungkinkan tanpa diskriminasi dengan pegawai lain.

5. Selama mendapat dukungan penuh dari lingkungan terutama keluarga, proses resiliensi tidak mengalami hambatan. Tim medis di rumah sakit termasuk sumber protektif yang berpengaruh bagi subjek, karena subjek menghabiskan waktu berbulan-bulan di rumah sakit untuk menjalani perawatan. Penemuan ini dapat menjadi penekanan bagi keluarga yang memiliki anggota keluarga penderita luka bakar atau memiliki ketidaksempurnaan fisik atau penampilan, bahkan peran dan dukungan keluarga sangat berpengaruh bagi penyesuaian subjek. Tim medis di rumah sakit pun semestinya terus-menerus meningkatkan kualitas pelayanannya karena menyadari bahwa tim medis memiliki pengaruh besar terhadap penyesuaian pasien.

6. Sebuah komunitas di jejaring sosial pun terbukti dalam penelitian ini sangat membantu subjek untuk melangsungkan kehidupannya dan memberi motivasi baginya, sehingga untuk komunitas tersebut, kiranya lebih diperbanyak dan lebih aktif dalam segala hal mengenai tema dari komunitas tersebut. Tidak hanya bagi subjek yang menderita luka bakar dan mengikuti komunitas di jejaring sosial yang bertemakan luka bakar, tapi komunitas-komunitas yang lain yang dapat bermanfaat bagi penderita lainnya, seperti penderita kanker, penderita trauma, dll.

7. Peneliti menyarankan untuk penelitian selanjutnya, agar dapat membandingkan kemampuan resiliensi pada perempuan dan laki-laki, sehingga menghasilkan hasil yang lebih unik. 


\section{DAFTAR PUSTAKA}

Campbell, L. (1976). Special Behavioral Problems of The Burned Child. American Journal of Nursing, Vol: 76, Page: 220-224.

Carvajal, H. F. (1990). Burns in Children and Adolescents: Initial Management as The First Step in Successful Rehabilitation. Pediatrician, Vol: 17, Page: 237-243.

El Hamaoui, Y. (2002). Post Traumatic Stress Disorder in Burned Patients. Burns, Vol:28, Page:647-650.

Fauerbach, J.A., Heinberg, L.W., Bryant,A.G., \& Richter, L. (2002). Coping With Body ImageChanges Following a Disfiguring Burn Injury. Health psychology Vol.21,115-121.

Grotberg, E.H. (1995). A guide to Promoting Resilience in Children : Strengthening the Human Spirut. Early Chidhood Development Practice and reflections Number 8. Bernard VanLeer Foundation.

Hurlock, E. (1995). Human development. New York: McGraw Hill.

Isaacson, B. (2002). Characteristics and Enhancement of Resiliency in Young People: A research Paper. (Tesis: The Graduate School University of Wisconsin-Stout).

Lawrence, J.W., Rosenberg, L.E, Fauerbach, J.A. (2007). Comparing the Body Esteem of Pediatric Survivors of Burn Injury With the Bidy Esteem of an Ag-Mathced Comparison Group Without Burns. Rehabilitation Psychology, V.52, No.4, 370-379.

Masten, A., \& Coatsworth, J. D. (1998). The Development of Competence in Favorable And Unfavorable Environments: Lessons From Research on Successful Children. American Psychologist, Vol: 53, Page: 205-220.

Papalia, D.E., Olds, S.W., \& Feldman, R.D. (2007). Human Development $10^{\text {th }}$ Ed. Boston: McGraw Hill.

Poerwandari, K. (2005). Pendekatan Kualitatif untuk Penelitian Perilaku Manusia. Depok: LPSP3.

Reivich, K. \& Shatte, A. (2002). The resilience factor : 7 essential skills for overcoming life's inevitability obstacles. New York: Broadway Books.

Ronawulan, E. (2009). Kondisi Psikologis pada Pasien Luka Bakar. Makalah dalam "Simposium Enlightment and Refreshment of Burn Management" di Universitas Indonesia, Depok pada 8-9 Agustus 2009 (tidak dipublikasikan).

Seifert, K. \& Hoffnung, R.J. (1987). Child and adolescent development. Boston; Houghton Mifflin Co.

Small, S. \& Memmo, M. (2004). Contemporary Models of Youth Development and Problem Prevention: Toward an Integration of Terms, Concepts, and Models. Family Relations. Vol. 53:, Page: 3-11.

Stoddard F. J. \& O'Connell K. G. (1983). Dysphoria in Children With Severe Burns. Journal of Children in Contemporary Society, Vol: 15, Page:41-50.

Schultz., P., Rodity M., Gillette,M. (2009). Resilience, Social Support, and Psychological Disturbance in Hispanic Women Residing in a Battered Women's Shelter on the U.S./Mexico Border. (2009) Hispanic Health Care International, Vol: 7 (4), Page: 224-230. 


\section{Internet}

Afz. (2010). Gedung Ramayana Terbakar , 41 Unit Mobil Kebakaran Diterjunkan, 02 April 2010. http://www. berita8.com/web8/berita/2010/02/gedung-ramayana-terbakar-41-unit--mobil-kebakaran-diterjunkan. Diunduh 30 Mei 2010.

Bautista, V., Roldan, A., \& Garces-Bacsal, M. (2007).Working with Abused Children from the Lenses of resilience and Contextualization. Save the Children Sweden, UP Center for integrative and Development Studies, and UP CIDS Psychososial Trauma and Human Rights Program. Diambil dari http://openlibrary.org/books/OL16285250M/Working_with_abused_children. Diunduh 23 Februari 2010

Benard, B. (2004). Resiliency. Diambil dari www.wested.org/online-pubs/resiliency/resiliency. Diunduh

2 Maret 2010.

Christle, C. A., Jolivette, K. N., \& Michael, C. (2000). Youth Aggression and Violence: Risk, Resilience, and Prevention. Diambil dari http://www.ericdigests.org/2001-4/youth.html. Diunduh 20 Maret 2010

Poerwantoro, P.D. (2008). Simposium Mini Luka Bakar Rumah Sakit Pusat Pertamina, 26 Januari 2008. Diambil dari http://lukabakar.net. Diunduh 7 Februari 2010

\section{Undang-undang}

Departemen Sosial Republik Indonesia. (1997). Panduan Pelaksanaan Pembinaan Kesejahteraan Sosial Anak Melalui Panti Sosial Asuhan Anak. Jakarta (tidak diterbitkan) 
